\title{
Corrosion hazards and inhibitor protection in the seawater injection system on the Baltic sea rig
}

\author{
K. Domanska, ${ }^{1} *$ P. Iglinski, ${ }^{2}$ J. Orlikowski, ${ }^{3}$ K. Zakowski ${ }^{3}$ \\ and K. Darowicki ${ }^{3}$ \\ ${ }^{1}$ Exploitation \& Reservoir Engineering Department, LOTOS Petrobaltic Ltd, 9 Stary Dwor \\ Street, 80-758 Gdansk, Poland \\ ${ }^{2}$ Production Maintenance Division, LOTOS Petrobaltic Ltd, 9 Stary Dwor Street, 80-758 \\ Gdansk, Poland \\ ${ }^{3}$ Department of Electrochemistry, Corrosion and Materials Engineering, Gdansk \\ University of Technology, 11/12 Gabriela Narutowicza Street, 80-233 Gdansk, Poland \\ *E-mail: kinga.domanska@lotospetrobaltic.pl
}

\begin{abstract}
Oil extraction efficiency in LOTOS Petrobaltic Company is increased by means of injection of seawater into an oilfield aquifer, which is implemented on the Baltic Beta rig, operating on the Baltic Sea. Operational experience has shown a significant degree of corrosion aggressiveness in the injected water, which necessitates frequent repairs of the seawater injection installation. Evaluation of the corrosion phenomena is crucial for rig platforms due to extremely high renovation costs and a negative impact on injected water quality. Chemical and microbiological analyses of seawater treated in the technological process have been carried out. Actions to estimate the corrosion risk in the installation and the estimated corrosion rates measured using an automated monitoring system are presented in this work. Monitoring of the corrosion rate conducted alongside measurements of the physicochemical properties of water allowed to identify the corrosion mechanisms of stainless steel in a seawater environment. Additionally, it became possible to assess the impact of the chlorine and carbon dioxide content on the corrosion rate, and to analyze the effectiveness of the corrosion inhibitor. The effectiveness of two types of commercial corrosion inhibitors has been estimated during different conditions.
\end{abstract}

Keywords: corrosion inhibitors, sea water injection system, linear polarization method, oil production.

Received: June 9, 2020. Published: July 28, 2020

doi: $\underline{10.17675 / 2305-6894-2020-9-3-9}$

\section{Introduction}

LOTOS Petrobaltic, as an upstream company, is involved in exploitation of oil in the Polish Marine Areas. To increase oil production, the method of seawater injection into an oilfield aquifer has been applied. Water flooding is a secondary recovery method in which water is injected into a reservoir to push the trapped hydrocarbons toward a producing area of the existing field. It increases the recovery factor $[1,2]$ but brings numerous risks, such as: rock 
permeability reduction near injection wells due to injection of suspended solids (including corrosion products), bacterial contamination of the formation $[3,4]$, which contributes to production of hydrogen sulfide and incurs potential corrosion risk [5].

Oil formation protection is extremely important. Injected water must feature strictly defined quality parameters [6,7], which is ensured by the seawater treatment installation operating on the Baltic Beta rig. A scheme of the seawater treatment system is presented in Figure 1.

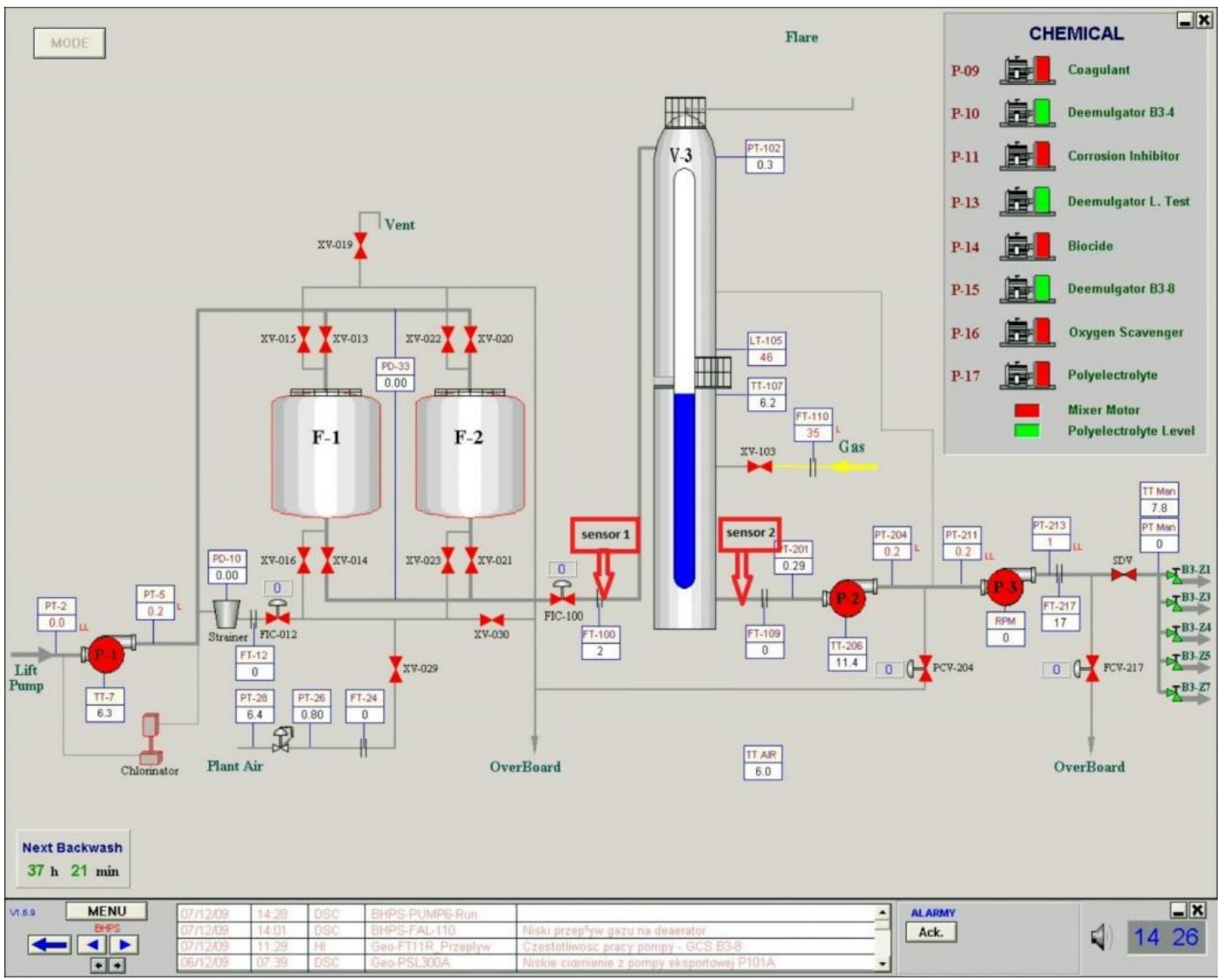

Figure 1. Scheme of the seawater injection system. Screenshot from the control screen.

The system takes seawater from seawater lift pumps located at the depth of 10 meters below sea level. An electro chlorinator is utilized where chlorinated water is fed into the suction to the filter feed pump (P-1). Chlorinated water ensures that the filter feed pumps, and media filters are protected from microbiological growth.

Next, the dosed water is treated in two 100\% dual media filters (F-1 and F-2). Such filters are designed to remove $98 \%$ of particles greater than $2 \mu \mathrm{m}$ in size. Coagulant and polyelectrolyte are dosed upstream of the filters to enhance filtration.

Water filtered in the dual media filters is next dosed with two types of biocides (for a period of 2 hours every 10 days), treated with UV light, and then further treated in a deaeration tower $(\mathrm{V}-3)$. The column is a packed bed tower in which oxygen is stripped 
through mass transfer from the water to the stripping gas (fuel gas in this case) separated from oil.

The gas is discharged to the flare system and stripped water is removed from the base of the column. Oxygen scavenger is dosed to the column water outlet to ensure that oxygen levels are below the specified value (20 ppb).

Thus, deoxygenated water is then transferred to the second booster pump (P-2), where it is ultimately pumped by the main injection pump (P-3) to maintain the pressure. A corrosion inhibitor is added to the water downstream of the deaerator, to protect the fittings against corrosion. A mixture based on high-boiling morpholine derivates is used nowadays. The P-3 pumps water through a high-pressure manifold into injection well bores.

The seawater injection system has been designed for $5,000 \mathrm{~m}^{3} /$ day but operated at $1,600 \mathrm{~m}^{3} /$ day, which is the minimum flow to avoid damage to injection pumps. However, such an injection volume is too high, and the system needs to be turned off for $\sim 20$ days each month.

During the turn-off period, the internal water circuit remains switched on. Water flows through the filters and deaerator at a flow rate of $80 \mathrm{~m}^{3} / \mathrm{h}$, the electro chlorinator and UV lamp are working, while polyelectrolyte and coagulant are being dosed. The stripping gas is shut in. Corrosion inhibitor dosing is switched off.

Oxygen corrosion, which is a major problem in seawater injection systems, is limited by the presence of oxygen as well as it is flow-dependent [8-10]. Another factor is the effect of chlorine used for microbial protection. Chlorine exacerbates the problem of erosion, thus creating conditions where corrosion rate is more dependent on flow velocity [11]. Corrosion may be affected also by scale activity, iron oxides, carbonates and sulfides [12]. Another common factor is the microbiologically influenced corrosion (MIC) caused by activity of sulfate-reducing bacteria (SRB) [13-15]. Film-forming corrosion inhibitors are particularly useful for preventing chloride, $\mathrm{CO}_{2}$, and $\mathrm{H}_{2} \mathrm{~S}$ corrosion.

With respect to bacterial and corrosion problems, the water injection system can be divided into two parts.

1.1. Upstream of the deaerator tower including the lift pumps, coarse filters and UV lamp. The very large surface area within the filter pod allows a rapid growth of aerobic heterotrophic bacteria (GHB). Due to activity of GHB, conditions in the filter pod become anaerobic, allowing SRB to become active. Residual chlorine and oxygen are present. Thus, corrosion risk is created.

1.2. From the deaerator to wellheads, including the deaerator tower and flowlines. In the deaerator tower oxygen is removed while oxygen scavenger is added. This product reacts with residual chlorine, so that downstream of the tower, residual chlorine concentration drops to zero. Due to usage of fuel gas with trace amounts of hydrocarbons and carbon dioxide, there are created very favorable conditions for SRB growth. This involves an injection of a non-oxidizing organic biocide. A corrosion inhibitor is added. Corrosion mechanisms may vary in this part of the installation [16]. 


\section{Experimental}

The operational experience of the Baltic Beta rig has shown a significant degree of corrosion aggressiveness of water, which necessitates frequent repairs of the installation, especially downstream of the dual media filters. Such a poor condition of the installation had a negative impact on the injected water quality. The average content of total suspended solids content in the last year was $2.25 \mathrm{mg} / \mathrm{l}$ and total iron content was $1.19 \mathrm{mg} / \mathrm{l}$. These values exceed the permissible quality indices for injected water. Figure 2 presents the actual state of the hatches of the dual media filters.

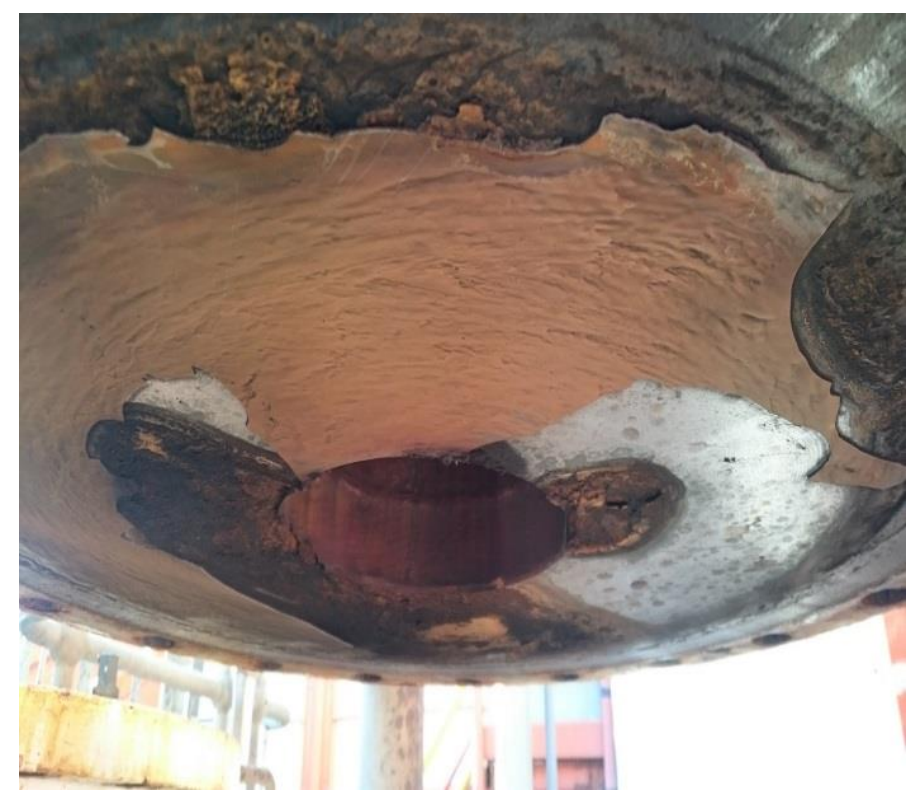

Figure 2. Surface of the inner parts of the dual media filter.

To assess corrosivity of water treated in the installation, the values of the parameters impacting the corrosion rate have been determined, which was done in the certified laboratory LOTOS Lab, with application of the ISO Standards. As the installation uses an alternating operation mode, it was necessary to assess the corrosion risk both, during the water injection and when only the internal circulation was used. Water sampled during both stages has been subjected to chemical analyses.

Contents of planktonic SRB and GHB were determined using the multiply dilution most probable number (MPN) method, as described in NACE TM0194-2004. Postgate B media for SRB and PRD media for GHB were used [17].

To devise an effective corrosion protection, first it must be determined what corrosion mechanism we are dealing with. Consequently, this necessitated a continuous monitoring of the corrosion processes taking place under the variable installation operating conditions. To this aim, there was designed and launched an automatic corrosion monitoring system. Monitoring of non-alloy steel corrosion consisted in a single point measurement of linear polarization performed by an automatic monitoring system. The measurements were taken 
at the interval of two hours using the sensors which are part of the installation, thus allowing the monitoring to be performed online. The points downstream of the dual media filters and downstream of the deaerator were monitored. The sensors have been constructed specifically to match the size of the installation. A complete sensor was made of stainless steel. To the casing there was attached a gland, in which a steel rod serving as a cable guide had been installed. The side of the sensor facing the pipeline was equipped with three electrodes for proper polarization. The electrodes were made of the S236JR steel.

The effectiveness of the corrosion inhibitor was tested in stationary conditions and in flow, a dose of $25 \mathrm{ppm}$ using. The action of another inhibitor was also tested.

\section{Results and Discussion}

The results of seawater analyses for presence of factors increasing the corrosion rate are tabulated in Table 1. It presents the results from the period when the injection system was operating with all the chemical additions and the water was being deoxygenated.

Table 1. The results of seawater analyses conducted at selected points of the installation, during the turnon period.

\begin{tabular}{ccccc}
\hline Parameter & Unit & $\begin{array}{c}\text { Downstream of the } \\
\text { lift pump }\end{array}$ & $\begin{array}{c}\text { Downstream of the } \\
\text { dual media filters }\end{array}$ & $\begin{array}{c}\text { Downstream of the } \\
\text { deaerator }\end{array}$ \\
\hline $\mathrm{pH}$ & & 8 & 7.9 & 7 \\
Chloride & $\mathrm{mg} / \mathrm{l}$ & 4200 & 4400 & 4400 \\
Calcium & $\mathrm{mg} / \mathrm{l}$ & 117.8 & 113 & 110 \\
Magnesium & $\mathrm{mg} / 1$ & 261.2 & 300 & 296 \\
Sulfates & $\mathrm{mg} / 1$ & 710 & 585 & 568 \\
Hydrogen sulfide & $\mathrm{mg} / 1$ & $<1$ & $<1$ & $<1$ \\
Carbon dioxide & $\mathrm{mg} / 1$ & 1.0 & 1.1 & 3.3 \\
Oxygen & $\mathrm{mg} / 1$ & 12.5 & 12.5 & 0.01 \\
Residual chlorine & $\mathrm{ppm}$ & 2.8 & 0.6 & 0 \\
Total suspended solids & $\mathrm{mg} / 1$ & 4.5 & 1.6 & 1.7 \\
Sulfides & $\mathrm{mg} / 1$ & $<0.02$ & 0.1 & $<0.02$ \\
Iron & $\mathrm{mg} / 1$ & $<0.02$ & 1.3 & 0.1 \\
\hline
\end{tabular}

Water composition changes at each step of the purification process in relation to the applied methods of chemical and physical treatment. One thing to note is a slight decrease in the $\mathrm{pH}$ level and reduced number of sulfates in the water downstream of the filters and deaerator tower. It is caused by the activity of sulfate reducing bacteria (SRB), which use sulfates in their metabolic processes and produce hydrogen sulfide. Following the treatment in the deaerator tower, the levels of oxygen and residual free chlorine decrease significantly, 
which reduces the corrosion risk. The content of aggressive carbon dioxide, however, is increased in deoxidized water. It may be associated with the applied physio-chemical deoxidation method which consists in passing of the gas accompanying the oil through a deaerator. The content of carbon dioxide in the gas is at the level of 0.15 mole\%. Carbon dioxide present in water decreases also its $\mathrm{pH}$ level.

When the water injection system was off (internal water circuit), only the parameters affected by changes of the installation operating mode were being determined. Table 2 presents the obtained results.

Table 2. Seawater analyses during the turn-off period.

\begin{tabular}{ccccc}
\hline Parameter & Unit & $\begin{array}{c}\text { Downstream of the } \\
\text { lift pump }\end{array}$ & $\begin{array}{c}\text { Downstream of the } \\
\text { dual media filters }\end{array}$ & $\begin{array}{c}\text { Downstream of } \\
\text { the deaerator }\end{array}$ \\
\hline $\mathrm{pH}$ & & 8 & 7.9 & 7.2 \\
Chloride & $\mathrm{mg} / \mathrm{l}$ & 4200 & 4400 & 4400 \\
Sulfates & $\mathrm{mg} / \mathrm{l}$ & 710 & 590 & 570 \\
Carbon dioxide & $\mathrm{mg} / \mathrm{l}$ & 1.0 & 1.1 & 1.1 \\
Oxygen & $\mathrm{mg} / \mathrm{l}$ & 12.5 & 12.5 & 12.5 \\
Residual chlorine & $\mathrm{ppm}$ & 2.8 & 0.2 & 0.2 \\
Total suspended solids & $\mathrm{mg} / \mathrm{l}$ & 4.5 & 2.8 & 2.8 \\
Sulfides & $\mathrm{mg} / \mathrm{l}$ & $<0.02$ & 0.2 & $<0.02$ \\
Iron & $\mathrm{mg} / \mathrm{l}$ & $<0.02$ & 2.5 & 2.2 \\
\hline
\end{tabular}

A decrease in the $\mathrm{pH}$ level and the sulphates content could also be observed in this period, which may be a sign of SRB activity in the filters and deaerator tower. The content of carbon dioxide is lower at the point downstream of the tower since there was no deoxidization and water did not meet the gas that accompanies oil. That is also the reason why the water is characterized by a high content of free chlorine and oxygen.

The results of the chemical analyses have been compared with the corrosion rates recorded by the automatic monitoring system using the linear polarization method.

The results obtained at a point downstream of the deaerator are presented in Figure 3.

The average rate of corrosion affecting the S236JR non-alloy steel remained at the level of $1 \mathrm{~mm} /$ year, which is ten times higher than the safe level of $0.1 \mathrm{~mm} / \mathrm{year}$.

The chart allows us to track how the water flow volume, free chlorine and oxygen contents in the water impact the corrosion rate. We can also see how a corrosion inhibitor works under various conditions. 


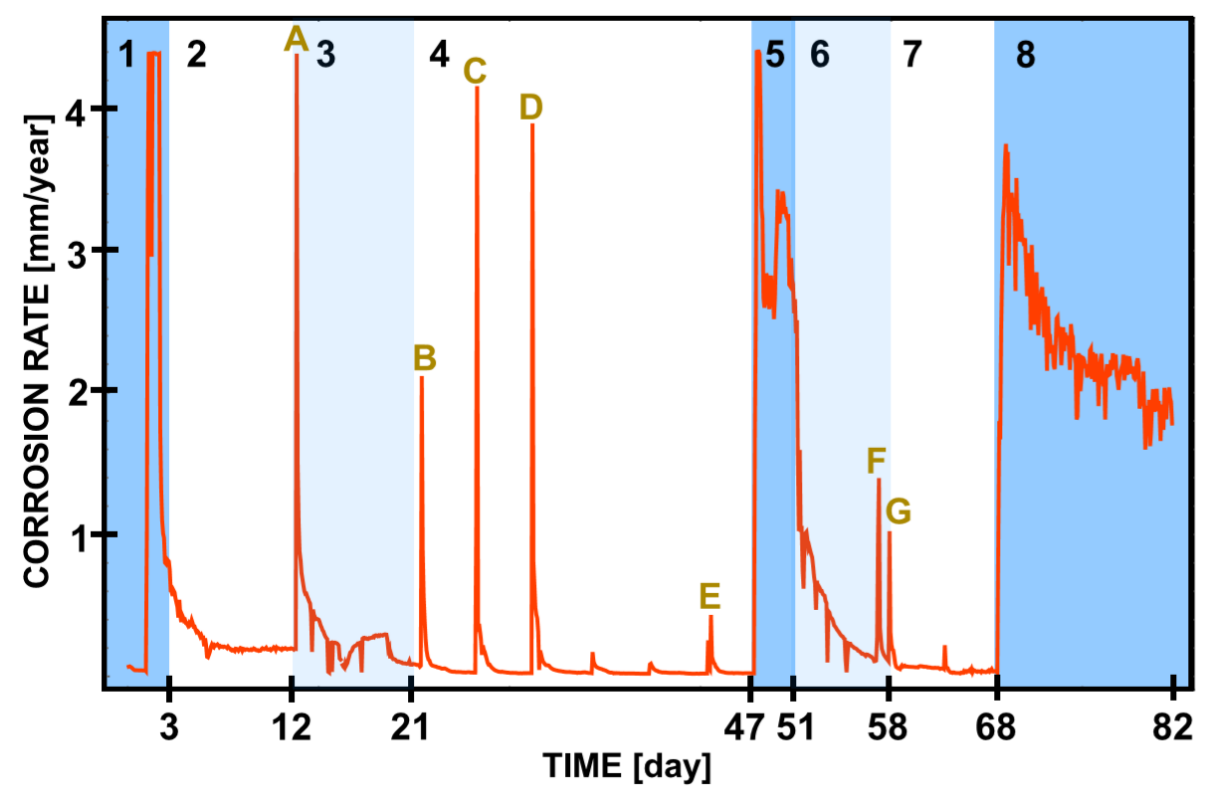

Figure 3. Corrosion rate measured at a point downstream of the deaerator tower (sensor 2).

In the periods 1, 5 and 8 (dark blue area), when the internal circuit was in use, the water flow through the installation amounted to $80 \mathrm{~m}^{3} / \mathrm{h}$, no deoxidization was performed, and the water chlorination process was carried out only to the point at which the free chlorine content reached the level of $0.2 \mathrm{ppm}$. Corrosion inhibitor was switched off. The average corrosion rates noted in these periods of time were, respectively, 1.68, 2.66 and $2.38 \mathrm{~mm} /$ year. Such high levels were associated with high water expenditures (erosion, corrosion), the presence of oxygen at the level of $12.5 \mathrm{ppm}$, free chlorine at the level of $0.2 \mathrm{ppm}$, and chlorides. In each of these periods the corrosion rate was decreasing gradually, indicating that some corrosion products might have developed on the metal surface.

In the periods 3 and 6 (light blue area), the process of water injections into the oil formation was being performed. The installation operated at the flow rate of $40 \mathrm{~m}^{3} / \mathrm{h}$, while water was being deoxygenated and corrosion inhibitor was added. The average levels of corrosion rate recorded in these periods were, respectively, 0.26 and $0.36 \mathrm{~mm} / \mathrm{year}$. The low oxygen content, lack of free chlorine, lower water flow rate and dosage of corrosion inhibitor brought the corrosion rate down significantly. Despite this fact, its level was still too high. This might prove the occurrence of MIC or low efficiency of the corrosion inhibitor. These periods were characterized also by a gradual decrease in the corrosion rate. However, the corrosion rate drops occurred faster here than in the periods when the internal water circuit was switched on. This is due to the lower water flow rate, which does not wash the corrosion products off from the inner surface of the pipes and an addition of a corrosion inhibitor. Peak $A$ in the area 3 shows when the water flow in the system was switched on and the corrosion products became detached. Peaks $F$ and $G$ in the area 6 result from temporary adjustments of the water flow rate. 
Very interesting results were recorded in the periods marked 2, 4 and 7 (in white), when the water flow through the installation was entirely shut off, In the first period (2), the installation was filled with water without a corrosion inhibitor. The average corrosion rate was $0.33 \mathrm{~mm} /$ year at the time. In the periods 4 and 7 the water flow was turned on every five days for a period of one hour in order to flush the equipment with water containing the corrosion inhibitor. The average corrosion rate in this period equaled 0.129 and $0.075 \mathrm{~mm} /$ year, which shows that the inhibitor used is highly effective under stationary conditions, when there is no water flow through the installation. Peaks $B, C, D$ and $E$ occurred when large flows of water treated with corrosion inhibitor were turned on, whole the smaller peaks correspond to turning the installation on with less expenditure.

The corrosion rate measurements from the same periods, obtained at a point downstream of the dual media filters, are presented in Figure 4.

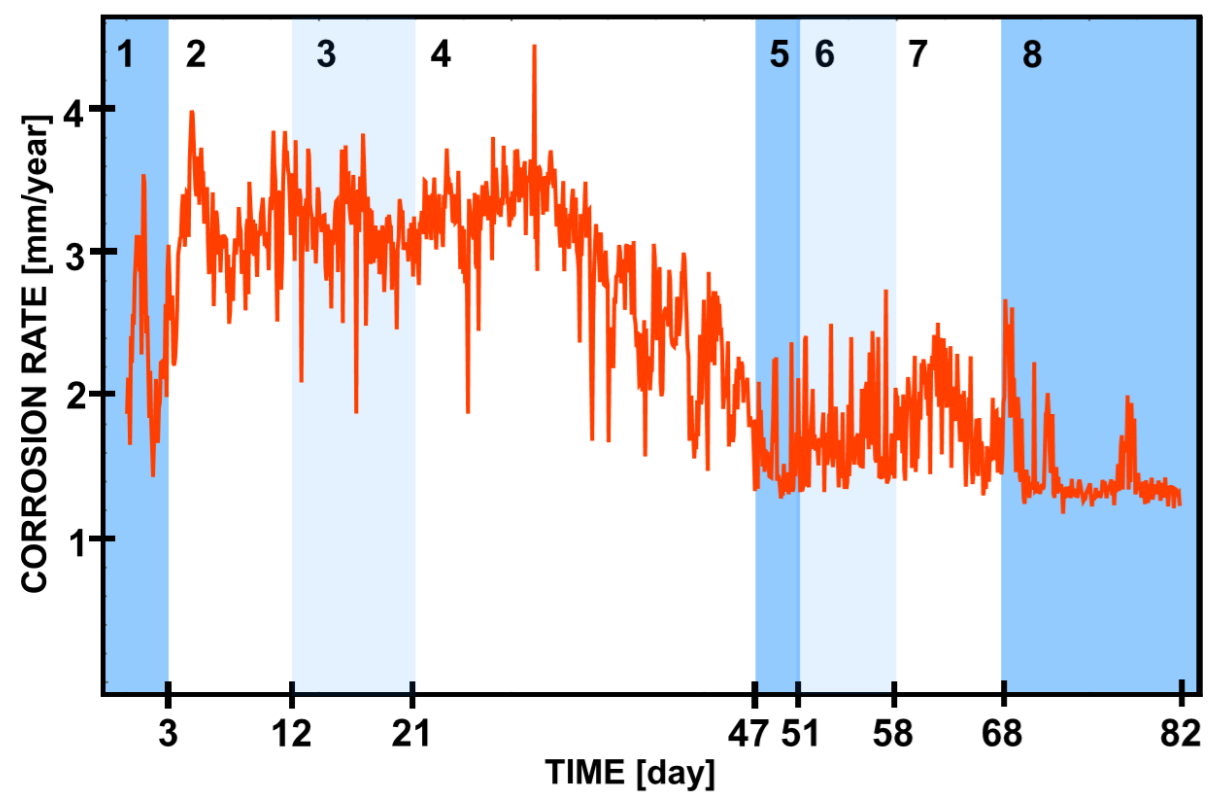

Figure 4. The corrosion rate measured at a point downstream of the dual media filters (sensor 1).

The average corrosion rate in non-alloy steel measured at a point before introduction of an inhibitor totaled $2 \mathrm{~mm} /$ year (which is twenty times higher than the safe level). The measured corrosion rates tended to oscillate. It was related to the fact that the installation was functioning on a periodic basis at the time. The noticeable oscillations match the devices operation schedule.

In the periods marked 1,5 and 8 (dark blue area), when the internal circuit was on, the average corrosion rates dropped down $(\sim 2.28,1.52,1.4 \mathrm{~mm} /$ year $)$. When the water was being injected (light blue area, marked 3 and 6) and flow rate was $40 \mathrm{~m}^{3} / \mathrm{h}$, the corrosion rate was higher $(3.07,1.65 \mathrm{~mm} /$ year). Hence, it can be noted that at this point the changes in the installation's operating mode did not have a significant impact on the corrosion rate measurements. The drop in the water flow velocity was not mirrored by a drop in the 
corrosion rate. It must be also noted that at times when water was not flowing through the installation, no significant drop in the corrosion rate could be recorded. At the time when the installation remained filled with water not treated with the corrosion inhibitor (white area marked 2), the corrosion rate was $3.05 \mathrm{~mm} /$ year, and in the periods marked 4 and 7 , when the filters were poured with water containing the corrosion inhibitor, the sensor recorded the corrosion rate of 2.74 and $1.78 \mathrm{~mm} / \mathrm{year}$. This may be a proof that chlorination of water in this part of the installation does not prevent biofilm development, and that MIC is the dominant corrosion mechanism here, which is why the corrosion inhibitor does not work properly.

We can also notice a decrease in the corrosion rate starting in the middle of period 4. Presumably, turning on a heavy water flow several times in period made some of the biofilm detach, thus slowing the microbiological corrosion rate.

Corrosion rate when using the second corrosion inhibitor are presented in Figure 5. Product was based on quaternary ammonium salts. The installation operated at the flow rate of $40 \mathrm{~m}^{3} / \mathrm{h}$, while water was being deoxygenated.

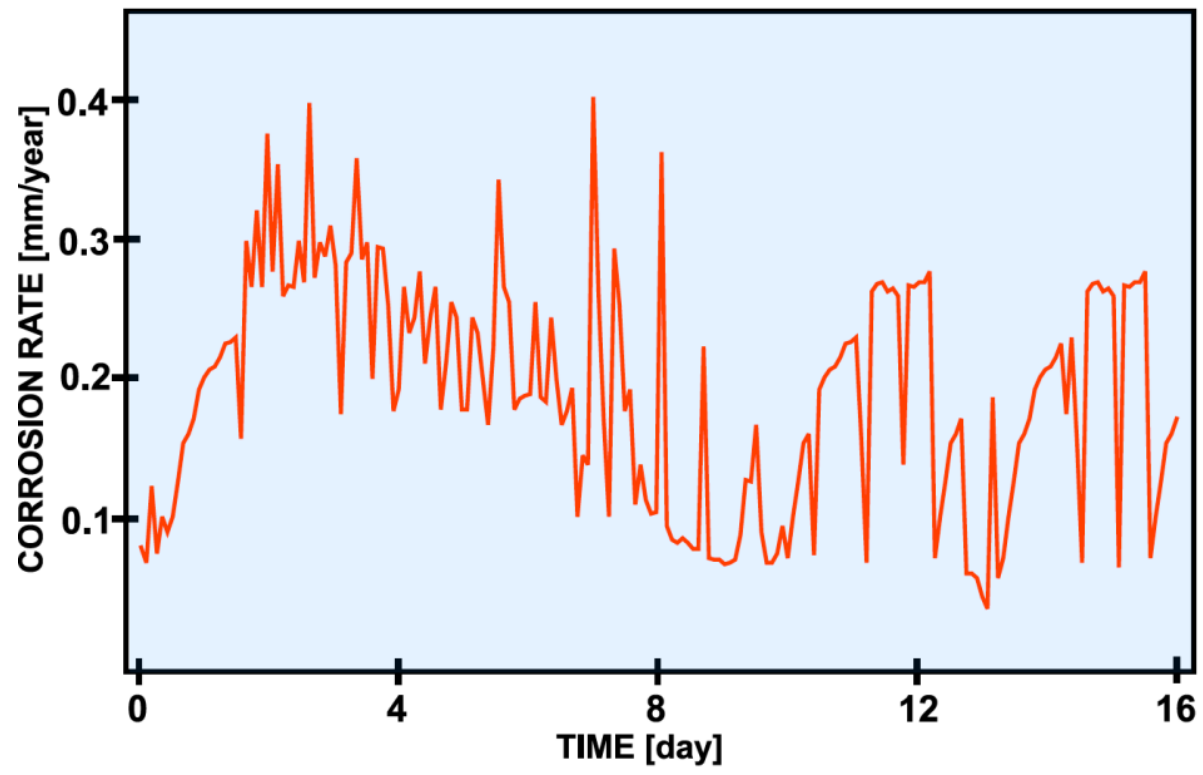

Figure 5. The corrosion rate measured downstream of the deaerator during the second inhibitor test.

The average corrosion rate during the test was $0.2 \mathrm{~mm} /$ year. This value is still too high, so the effectiveness of the tested inhibitor was poor. Similar to the corrosion inhibitor used previously.

It had to be checked if what we are dealing with is MIC and whether the increased corrosion is caused by the activity of SRB which have proliferated inside the installation.

Table 3 presents the content of GHB and SRB planktonic bacteria in the water and the corrosion rate. The biological analyses have been performed by the specialists of the LOTOS Petrobaltic company, based on samples collected directly from the installation. 
Table 3. GHB and SRB content in the water and the corrosion rate at points located downstream of the dual media filters and downstream of the deaerator.

Downstream of the dual media filters

\begin{tabular}{ccccccccc}
\hline Flow rate $\left(\mathrm{m}^{3} / \mathrm{h}\right)$ & $\mathbf{8 0}$ & $\mathbf{0}$ & $\mathbf{4 0}$ & $\mathbf{0}$ & $\mathbf{8 0}$ & $\mathbf{4 0}$ & $\mathbf{0}$ & $\mathbf{8 0}$ \\
GHB (unit/ml) & 1100 & $1400+$ & 450 & $1400+$ & 950 & 45 & $1400+$ & 1100 \\
SRB (unit/ml) & 35 & 45 & 25 & 250 & 45 & 4.5 & 150 & 45 \\
Corrosion rate (mm/year) & 2.28 & 3.05 & 3.07 & 2.74 & 1.52 & 1.65 & 1.78 & 1.4 \\
\hline & Downstream of the deaeration tower & & & \\
\hline GHB (unit/ml) & 350 & $1400+$ & 25 & $1400+$ & 1100 & 25 & $1400+$ & 250 \\
SRB (unit/ml) & 2.5 & 95 & 2.5 & 250 & 4.5 & $<0.3$ & 150 & 4.5 \\
Corrosion rate (mm/year) & 1.68 & 0.33 & 0.26 & 0.129 & 2.66 & 0.36 & 0.075 & 2.38 \\
\hline
\end{tabular}

It should be noted that only planktonic bacteria, swimming freely in the water, were analysed. In the periods when the water flow through the installation was shut off, the content of GHB and SRB was very high. The lack of biocide treatment created favourable conditions for biofilm development on the inner sides of the devices. At a point located downstream of the dual media filters, the number of GHB and SRB remained high also when the internal circuit was in use, as the levels of free chlorine in the water were too low at the time. In this period, the section downstream of the deaerator tower was protected by a UV lamp which is installed upstream of the deaeration tower. The results indicate a high effectiveness of UV radiation.

\section{Conclusions}

An analysis of the results presented in this work confirmed that corrosion in water downstream of the dual media filters is of a different nature than corrosion at a point downstream of the deaerator tower as it is associated primarily with water oxygenation and impact of residual chlorine, which is used for microbial protection of this section of the installation. Also, occurrence of microbiologically influenced corrosion can be noticed in this part of the installation. Corrosion downstream of the deaerator tower is limited by a low content of oxygen and the presence of the corrosion inhibitor. Carbon dioxide and bacteria contents in the water impact the rate of corrosion affecting this part of the installation.

A comparison of the measured corrosion rates with the contents of SRB and GHB showed only a partial correlation between these parameters. However, it must be underlined that only bacteria swimming freely in the water were analyzed. This indicator demonstrates only the potential of water to develop a biofilm. In the future, the number of bacteria in the biofilm will have to be determined to assess the possibility of MIC occurrence, as activity of bacteria proliferating in the biofilm is the main factor behind corrosion of this type. There will have to be performed a mechanical cleaning of the installation and find a new inhibitor 
preventing microbiological corrosion more successfully (which may prove difficult). It is particularly important to develop a means of biological protection for the section of the installation upstream of the deaeration tower for the times when only the internal circuit is used.

It should be noted that monitoring the corrosion rate conducted alongside measurements of the physicochemical properties of water allowed to identify the following corrosion mechanisms:

- microbiological corrosion,

- electrochemical corrosion using oxygen depolarized cathode,

- erosion, corrosion.

Additionally, it became possible to assess the impact of the chlorine and carbon dioxide content on the corrosion rate, and to analyze the assessed effectiveness of the corrosion inhibitor. The proposed measurement methods enabled us to explain what causes corrosion despite the occurrence of numerous corrosion mechanisms.

We also had the opportunity to assess the effectiveness of two types of corrosion inhibitors. None of them provided sufficient protection. It seems that the biological protection will play a key role in corrosion prevention.

\section{Conflicts of interest}

The authors declare no financial conflicts of interest regarding the publication of this paper.

\section{Acknowledgments}

The publication has been written thanks to the government's "Industrial European Doctorates" (in Polish: Doktorat Wdrożeniowy) program.

\section{References}

1. J. Lubaś, W. Szott and M. Dziadkiewicz, Analiza możliwości zwiększenia stopnia sczerpania zasobów złóż ropy naftowej w Polsce, Nafta-Gaz, 8, 2012, 481-489 (in Polish).

2. T. Clemens, G. Kienberger and M. Persaud, Optimizing water-injection design in a shallow offshore reservoir, SPE Prod. Oper., 32, no. 4, 2017, 551-563. doi: 10.2118/180143-PA

3. D.E. Hockaday, Water quality requirements in oil field fluid injection operations, a digest of the proceedings of the short course - water quality control for subsurface injection, University of Oklahoma, Norman, Okla., 1958, 9-10.

4. J.E. Donham, Offshore water injection system: Problems and solutions, Offshore Technol. Conf., Houston, Texas, 1991, 773-782. doi: 10.4043/6782-MS

5. S. Maxwell, Predicting microbially influenced corrosion in seawater injection systems, SPE International Oilfield Corrosion Symposium, SPE J. (Soc. Pet. Eng.), Aberdeen, 2006, 1-8. doi: 10.2118/100519-MS 
6. J. Rochon, M.R. Creusot, P. Rivet, C. Roque and M. Renard, Water quality for water injection wells, SPE Formation Damage Control Symposium, SPE J. (Soc. Pet. Eng.), 1996, 489-503. doi: 10.2118/31122-MS

7. C.C. Wright, Water-quality and corrosion control for subsurface injection, Drilling and Production Practice, Am. Pet. Inst., 1960, 134-139.

8. T. Eggum, N. Tajallipour, S. Arumugam, P. Teevens, Comprehensive approach to oxygen corrosion analysis of water injection systems, CORROSION 2015, NACE Int. Corros. Conf. Ser., Dallas, Texas, 2015.

9. S. Dong, W. Liu, J. Zhang, X. Lin, J. He and M. Lu, Effect of oxygen on $\mathrm{CO}_{2}$ corrosion and erosion-corrosion behavior of N80 steel under high temperature and high pressure, CORROSION 2014, NACE Int., San Antonio, Texas, 2014.

10. R. Barker, X. Hu, A. Neville and S. Cushnaghan, Flow-induced corrosion and erosioncorrosion assessment of carbon steel pipework in oil and gas production, CORROSION 2011, NACE Int., Houston, Texas, 2011.

11. M.N. Noui-Mehidi and W.O. Badeghaish, Understanding erosion patterns as potential sites for corrosion proliferation, Abu Dhabi International Petroleum Exhibition \& Conference, SPE J. (Soc. Pet. Eng.), Abu Dhabi, 2019. doi: 10.2118/197505-MS

12. M. Ciolkowski and A. Neville, A systematic scale-corrosion study of a combined inhibitor in scale-corrosion environment via experimental design, NACE-International Corrosion Conference Series, NACE Int., San Antonio, Texas, 2014.

13. J.L. Crolet, Microbial corrosion in the oil industry: a corrosionist's view, Am. Soc. Microbiol., Washington, USA, 2005, 143-170. doi: 10.1128/9781555817589.ch8

14. L. Latifi, M. Berry and S. Maxwell, Mitigation of microbiologically influenced corrosion in water injection flowlines, CORROSION 2007, NACE Int., Nashville, USA, 2007.

15. R. Javaherdashti, Microbiologically influenced corrosion (MIC), Springer, Cham, 2979. doi: $10.1201 / \mathrm{b} 14703-7$

16. T.D. Gier, Microbiologically influenced corrosion in mooring systems-field experience, Offshore Technol. Conf., Houston, USA, 2014. doi: 10.4043/25375-MS

17. Field monitoring of bacterial growth in oil and gas systems, NACE Int., 2014. 